\title{
COTIDIANO E REFLEXIVIDADE
}

\author{
José Machado Pais
}

\begin{abstract}
RESUMO: Tomando-se o cotidiano como alavanca metodológica do conhecimento, analisam-se as tensões resultantes do embate entre diferentes tipos de reflexividade. Nomeadamente, quando a reflexividade impositiva (orientada pelo passado) se confronta com a reflexividade transformadora (orientada para o futuro) geram-se situaçôes dilemáticas que fazem com que o cotidiano se assuma cada vez mais como um terreno de negociações, resistências, inovações e, consequentemente, de dilemas. Dilemas banais do cotidiano são analisados como o uso da gravata, os comportamentos sexuais ou as condutas nas filas de trânsito. As conclusōes sugerem que a modernidade não deve ser apenas entendida como um empolamento de opções; que a subjectivação não se opóe à socialização; e que a individualização pode gerar uma falsa consciência de libertação.
\end{abstract}

Palavras-chave: Cotidiano. Identidade. Reflexividade. Modernidade. Socialização.

\section{QUOTIDIAN AND REFLEXIVITY}

ABSTRACT: Taking the quotidian as the methodological leverage of knowledge, we analyze the tensions resulting from the collision between different types of thinking. Namely, the opposition between imposing reflection (oriented towards the past) and transforming reflection (oriented towards the future) create dilemmatic situations, which lead the quotidian to be increasingly assumed as a field of negotiations, resistance, innovation and, consequently, dilemmas. Trivial quotidian dilemmas are analyzed, as using a tie, sexual behaviors or conducts in traffic jams. Our conclusion suggests that modernity should not only be understood as a blistering

Doutor em Sociologia e pesquisador do Instituto de Ciências Sociais da Universidade de Lisboa. E-mail: machado.pais@ics.ul.pt. Página pessoal: http://www.jose-machado-pais.net 
of options, that the subjectivation process is not opposed to socialization, and that individualization can generate a false awareness of liberation.

Key words: Quotidian. Identity. Reflexivity. Modernity. Socialization.

\section{Introdução}

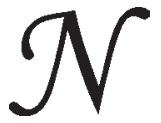

o último Congresso da Associação Portuguesa de Sociologia, realizado na cidade de Braga, em 2004, convidaram-me a participar numa mesa-redonda sobre "Sociologia e Sociedade: reflexividade e acção". Quando tomei a palavra, comecei por saudar os assistentes com um "bom-dia" cordial. Seguiram-se momentos de silêncio. De entre os cerca de mil congressistas presentes ninguém se dignou corresponder à minha saudação. Não interpretei esse silêncio como uma afronta, muito menos como sintoma de "má educação". É que esta reflexividade reactiva - corresponder a uma saudação - não é habitual quando alguém dá bom-dia a um receptor massivo que, supostamente, apenas deve intervir em período de debate, se tempo sobra para isso. No bar, durante o coffee-break, cruzei com vários colegas e os "bonsdias" saltitavam de boca em boca como uma bola de pingue-pongue. Ou seja, a reciprocidade (modalidade mole da reflexividade) depende do contexto. ${ }^{1}$

Quer isso dizer que, apesar de vivermos tempos de modernidade reflexiva (Giddens, Beck \& Lash, 1995), ${ }^{2}$ existem ordens normativas que continuam a reflectir-se nos actos comunicativos da vida cotidiana, muitas vezes de forma impositiva. Esta particularidade - a de as nossas acções reflectirem ordenamentos culturais - traduz uma reflexividade impositiva, não por acaso incorporada em muitos provérbios, ou não fossem eles bússolas de orientação normativa: ao sugerirem necessidades de aculturação ("Na terra onde fores viver faz como vires fazer"), efeitos de socialização ("Quem lida com um coxo aos três dias manqueja") ou estruturas de oportunidade (“A ocasiāo faz o ladrão”).

Contudo, as convençôes sociais reproduzidas no dia-a-dia estão pendentes de um controlo reflexivo por parte dos sujeitos. Sujeitos a quê? Ao peso dessas convenções, embora de um modo não inevitável. Quer isso dizer que entre realidade (normativa) e reflexo (cultural) não há uma simples correspondência mecânica, há também oportunidade para que 
esse "reflexo cultural" possa intervir na reconstrução da "realidade social”, ou seja, há lugar à reflexividade transformadora, à capacidade de intervenção na realidade, passando pela modificação das representações que a reflectem (Calvo, 2001, p. 136 e seguintes) - o que pode dar origem a novas representações que, sendo efeito dessa reflexividade transformadora, passam a ser legitimadas na sua circulação social. Mesmo a linguagem proverbial não escapa a esse tipo de reflexividade transformadora, estabilizando-se depois em novo senso comum. Exemplos: "Águas passadas não movem moinhos"; "Quem não considera, não reconsidera”; "Quem não chora não mama” etc.

Ao contrário do que alguns teóricos da modernidade reflexiva sugerem, não me parece que a um estádio de reflexividade impositiva (orientada pelo passado) se siga outro de reflexividade transformadora (orientada para o futuro). ${ }^{3} \mathrm{O}$ que se torna necessário é fugir a falsas linearidades (Lash, 2003), enfatizando a relação espelhada entre ambos os tipos de reflexividade, embora, é certo, os tempos da modernidade reflexiva sejam tempos de predominância da reflexividade transformadora - de uma reflexividade que toma o cotidiano como um campo aberto à experiência.

Aliás, a tensão entre esses dois tipos de reflexividade é geradora de situaçôes dilemáticas que fazem com que o cotidiano se assuma cada vez mais como um terreno de negociações, de resistências, de inovações e, consequentemente, de dilemas. Estes últimos decorrem dos "cenários de suposição" em que vivemos, onde a incerteza nos governa, ${ }^{4}$ perante a incognoscibilidade do futuro. As instituições tornam-se produtoras de ameaças que não conseguem controlar. ${ }^{5} \mathrm{~A}$ reflexividade da modernidade não actua em condições de certeza progressiva, mas de dúvida metódica. A nossa sociedade, mais do que uma sociedade de "risco" - é uma sociedade dilemática. E é por isso que boa parte da sociologia de Giddens é usando uma metáfora da tauromaquia - uma "pega de caras"6 ao risco por entre os cornos da "colonização do futuro" e da "segurança ontológica” (Giddens, 1995a).

Os "dilemas de vida" colocam-nos na posição de ter de tomar decisões. E porque assim é, Giddens fala-nos de uma estranha aparição, a "política de vida", repetindo, insistentemente, que ela é uma "política de decisões de vida" (idem, ibid., p. 272) que afectam a "identidade do eu”. Por exemplo, por meio dos investimentos na imagem corporal. 
O próprio corpo emancipou-se, como condição para a sua reestruturação reflexiva. Se, ao princípio, se acreditava que era o lugar da alma e, mais tarde, o centro de necessidades obscuras e perversas, o corpo é agora plenamente susceptível de ser "trabalhado" pelas influências da modernidade recente. (p. 275)

Para justificar as múltiplas possibilidades de escolha, no que toca aos investimentos corporais, Giddens invoca os "sistemas abstractos" que se reflectem num número crescente de guias e manuais práticos relacionados com a saúde, a dieta, a aparência, a prática de sexo etc. Francamente, não sei se uma tal literatura nos garante uma emancipação do "eu". Provavelmente apenas sugere uma falsa consciência de emancipação. É certo que os dilemas de vida e as opções que somos levados a tomar jogam, aparentemente, a favor da afirmação da identidade do eu... Mas em que medida é que essas "políticas de vida" nos salvam, inevitavelmente, das teias de constrangimentos sociais em que continuamos a viver, tanto mais alienadamente quanto menos delas nos damos conta?

\section{O dilema da gravata}

Na manhã da minha mesa-redonda tinha acordado com um dilema que mostra bem como a reflexividade faz parte do cotidiano. O dilema matinal era bem banal: deveria usar ou não gravata? Digamos que o dilema já se insinuara em Lisboa quando procedi à arrumação da bagagem com que viajei até Braga. Aí o dilema era decidir sobre se levar gravatas, quantas e quais. Acabei por levar duas, a das bolinhas e a azul das riscas opção que sempre provoca em minha companheira uma reacção reflexiva, num misto de exclamação (induzida pela recorrência do uso) e de interrogação (perante a minha injustificável insistência): "Outra vez as mesmas gravatas!?”. Como perceberão, o problema das identidades reflexivas não é somente o de ter opções mas, sobretudo, o de ter de optar (Sweetman, 2003). Que razões ou motivos fundamentaram a minha opção? Quando me olho ao espelho sem gravata, ou com gravata às bolinhas ou às riscas, qual a imagem que reflecte o espelho em que me miro? A construção de uma identidade individual ou social?

Os teóricos da modernidade reflexiva sustentam que os tempos que correm dão mais e mais oportunidades às chamadas "biografias reflexivas", biografias do tipo "faça você mesmo", biografias que se despem de destinos pré-fabricados para, elas próprias, se assumirem construtoras dos seus pró- 
prios destinos (Giddens, 1995a). Mas, na verdade, acabei por ir para a mesa-redonda enforcado na gravata (as riscas destronaram as bolinhas) e o "faça você mesmo" restringiu-se ao dar o nó na gravata. De nada me valeu um tratado de dois conceituados físicos da Universidade de Cambridge (Fink \& Mao, 2002) que me prometiam revelar todo o potencial das voltas e laçadas do nó da gravata, libertando-me da tirania da escolha limitada. Ou seja, na prática, há limites à reflexividade transformadora. Limites que são reflexo de contextos e de atributos sociais: por se ser mulher, por se ser negro, até por se ser sociólogo. Não por acaso andei de olho nas mesas-redondas já realizadas ${ }^{7}$ para ver se havia algum padrão orientador, qualquer regime consensual de "adereço individual", ${ }^{8}$ algo que me ajudasse à definição de um "tipo ideal" de sociólogo de mesa-redonda, produto de uma reflexividade que poderíamos designar de aglutinadora, ao fazer repercutir comportamentos noutros comportamentos, por meio de um efeito mimético. Fiz uma contagem freqüencial das gravatas presentes nas mesas-redondas (sessões plenárias) entretanto ocorridas e verifiquei que elas quase fizeram o pleno. $\mathrm{O}$ desvio com relação ao "padrão" foi quase nulo. ${ }^{9}$ Mas, por azar, logo a minha mesa-redonda (a última, antes da sessão de encerramento) haveria de calhar a um sábado. Como sabem, são conhecidos os efeitos desestabilizadores do fim de semana, ao injectar laivos de informalidade nas relações sociais, desaglutinando o aglutinado.

Eu desejava que levassem a sério o embaraço provocado pelo meu dilema. Ao fim e ao cabo, a aparência é um elemento fundamental do "projecto reflexivo do eu". O desenvolvimento do "eu" depende sempre do domínio das respostas apropriadas às expectativas dos outros. Um indivíduo que teime em ser "diferente" de todos os demais, mesmo que seja sociólogo, não tem possibilidades de desenvolver reflexivamente uma identidade coerente do seu "eu" (Giddens, 1995). O embaraço dilemático é correlato natural de qualquer tipo de ameaça, de qualquer risco. No caso presente, risco de comportamento desenquadrado. Ora, uma característica da modernidade, como nos diz Giddens (op. cit., p. 26), é termos de decidir sobre como viver, que comer, que vestir, incluindo usar ou não gravata. É claro que vivemos numa sociedade de livre-arbítrio, mas as convençóes ainda pesam, disso sendo prova a ubiquidade da gravata. Usar ou não gravata é um dilema como tantos outros que se inscrevem numa espécie de ritual de arrumação. É um dilema reflexivo da "apresentação do eu na vida cotidiana" para usarmos a terminologia com que Goffman titulou uma das suas mais conhecidas obras. Quando coti- 
dianamente nos confrontamos com o espelho, despendemos tempo, paciência e ansiedade porque nos sujeitamos a uma espécie de escrutínio público imaginado. Dir-me-ão: "Se você vier aqui ao Brasil, esqueça o dilema, a gente não repara nisso!". Não é tanto assim. Já tenho participado em alguns congressos brasileiros e, apesar do calor e da informalidade reinante, constatei que as gravatas marcam também presença nas mesas-redondas. Como justificar o facto de tantos de nós - os das hostes masculinas - transformarmos a gravata numa espécie de "couraça protectora" que nos faz repousar as inquietaçôes de imagem na tranquilidade de uma "segurança ontológica"? De resto, sabemos que uma das características da modernidade reflexiva sugere a possibilidade de as acções cotidianas de um indivíduo se poderem repercutir nos demais (Giddens, Beck e Lash, op. cit., p. 75). Nada de novo. O próprio conceito de interacção, tal como Goffman (1993) o definiu, remete para a influência recíproca dos indivíduos entre si.

Não sei se já repararam, estou a armar-vos uma ratoeira etnometodológica. $\mathrm{Na}$ etnometodologia, a reflexividade pressupõe que as descrições não sejam apenas descrições de algo mas que, sobretudo, produzam algo. Elas não se limitam a representar a realidade, também ajudam a criá-la (Coulter, 1990). Quando, por exemplo, os etnometodólogos realçam a natureza reflexiva do discurso, colocam em causa o dualismo que contrapõe a descrição à realidade descrita. A reflexividade implica que qualquer descrição seja uma referência a algo, mas, ao mesmo tempo, faça parte desse algo. As descrições não são apenas usadas por seu carácter descritivo. Elas são acções sociais. E vocês, pelo simples facto de me estarem a ler, participam na minha acção comunicativa.

Neste sentido, ao convidar-vos a reflectir sobre o dilema da gravata arrasto-vos para uma reflexão sobre os próprios dilemas da reflexividade. A decisão de vos falar do dilema induz, implicitamente, o reconhecimento de que essa decisão tem interferência sobre quem me lê. Por outras palavras, o meu "dilema" tem reflexos reais. A partir do momento em que dele vos falo, o meu dilema passa a ser um dilema compartilhado - ainda que sempre tenham o direito de pensar que é um dilema idiota. Mas até os dilemas idiotas podem ser pensados por sociólogos sensatos. É Giddens (1995a, p. 57) quem nos sugere que "uma submissão cega às rotinas estabelecidas (...) é sinal de compulsão neurótica". Quando me questiono sobre o uso da gravata, em que tipo de identidade se enraíza minha opção? Num gosto individual? E como 
se forma esse gosto? Em que medida meu gosto não será determinado pela forma como penso que me gostariam de ver? Se assim for, o meu gosto estará embutido num habitus - como diria Bourdieu -, que só não é determinístico porque, na medida em que o questionamos, estamos a dotá-lo de uma aura de reflexividade. Trata-se de uma reflexividade primordial que desestabiliza os consensos pelo simples facto de os questionarmos. É uma reflexividade que deriva da propensão de os habitus serem - em sociedades de modernização reflexiva - crescentemente flexíveis e reflexivos (Sweetman, 2003, p. 529). Os horizontes da reflexividade individual estão estreitamente dependentes da reflexividade inerente aos habitus. Quando, com 9 anos, fiz o meu exame de "ensino básico", não tive margem de escolha; em tais circunstâncias a ditadura salazarista obrigava os examinandos ao uso da gravata. Agora posso questionar-me sobre o uso da gravata. Como sugere Giddens (1995, p. 11), a modernidade institucionaliza o princípio da dúvida radical, característica essencial do mundo contemporâneo. $\mathrm{Na}$ língua inglesa, gravata é tie - palavra que também remete para a ideia de corrente, laço, ligação, vínculo. Questionar a influência dos vínculos sociais sobre as nossas acções, bem como a capacidade de deles nos podermos libertar, está no âmago da discussão da reflexividade. Tanto mais que, por efeito de uma reflexividade centrada na "identidade do eu", na esfera do intimismo, importa discutir se os fenómenos sociais, à força de se desprenderem dos sociocentrismos, convertem-se em meras questôes de personalidade, despojadas do social.

\section{O conhecimento de si e o reconhecimento por parte dos outros}

Um dos cenários onde as identidades mais aparentam ser resultado de escolhas individuais é o do consumo. A liberdade de "eleição individual" converte-se num "marco envolvente da expressão individual do eu" (Giddens, 1995, p. 250). Na literatura sociológica mais vanguardista há quem sugira a passagem de modos socializados a modos privatizados de consumo (Wagner, 1994; Featherstone, 1991); desvalorizam-se as teorias das classes sociais e da estratificação que fazem finca-pé na associação dos actos de consumo à condição social de quem consome; advoga-se, com firmeza, que todo o consumo corresponde a um "projecto de vida" individual, a uma distintividade puramente individual - sem lugar para o social. O corpo é descoberto como 
um corpo individual, reflexivamente mobilizado, como se outrora os corpos fossem corpos mortos, de tão sociais o serem.

No entanto, a afirmação do eu não significa apenas um conhecimento de si próprio mas um reconhecimento de si por parte dos outros. São os outros que falam de mim sem que eu o saiba, que me objectivam encerrando-me numa imagem que é mais real do que a realidade de quem sou. Arbitrariedade insólita esta, a de ver-me despojado de mim mesmo por efeito da imagem que os outros fazem de mim. E porque não apenas sou o que penso de mim mas a imagem que os outros de mim constroem, acabo por me disseminar na representação dos outros, na qual me olho ao espelho para me reaprender. Essa aprendizagem de mim mesmo, quando me olho na imagem espelhada das representações dos demais, permite recuperar essa coisa estranha que sou para mim mesmo só pelo simples facto de o ser para os demais. Este é um género de reflexividade induzida pelo outro.

O dilema da gravata mostra que as identidades quando se enfrentam com alternativas opcionais tendem a uma individualização, embora não deixem de ser construídas na base de consensos sociais - consensos precários, evidentemente, postos à prova no dia-a-dia, permeáveis ao fluir das práticas cotidianas. Por esta razão, o cotidiano é, por excelência, um terreno de reflexividades. É a partir do cotidiano que podemos reconhecer que a liberdade de opção, que é própria da reflexividade de acção, pode traduzir-se em ganhos de autonomia, mas também em perdas de aceitabilidade. As "enfermidades do individualismo" (Bruckner, 1999, p. 14-15) acabam por reflectir uma preocupação: a de escapar às consequências dos próprios actos; a de procurar gozar dos benefícios da liberdade sem sofrer dos seus inconvenientes. Entre a rotina, a representação das convençôes e os sentimentos de "segurança ontológica" estabelecemse vínculos que expressam ambivalências profundas. Por isso o dilema: Que vão pensar de mim se, na minha mesa-redonda, meu pescoço for o único sem gravata? Pensarão que estou a abandalhar a mesa? Que sou um snob de "esquerda" que subordino compromissos políticos a uma tira de tecido? Admitirão que, sem gravata, sou tanto ou mais preconceituoso do que aqueles que dela não prescindem? Todas estas inquietações derivam do facto de a gravata incorporar um conjunto de propriedades simbólicas transferíveis para quem a coloca ao pescoço.

Não tenho dúvida em concordar que, na chamada "modernidade reflexiva”, mais e mais possibilidades temos de afirmar a nossa individuali- 
dade. Mas também é certo que continuamos a ser semelhantes no modo como nos pretendemos distinguir. Somos relativamente previsíveis nos nossos mais espontâneos actos, mesmo quando esses actos se constituem em dilemas. É isso que a sociologia nos mostra - por vezes com exageros, é bom que se diga - quando ridiculariza as pretensões ao ineditismo artificial. Um homem (ou uma mulher) pode alimentar a ilusão de usufruir o estatuto de amante excepcional e de apenas se deixar apaixonar por mulheres (ou homens) verdadeiramente excepcionais. A (falsa) consciência desta essência reflexiva pode até alimentar o seu superego, o seu lado narcisista. Mas depois, desoladoramente, lá vêm as sondagens sociológicas mostrar que o atributo de "amante excepcional" é compartilhado por $80 \%$ dos seus compatriotas com o mesmo nível de habilitações literárias, o mesmo caudal de rendimentos, o mesmo acervo de electrodomésticos ou a mesma cilindrada de automóvel (para apenas reter algumas das variáveis que integram a famosa escala de Warner, usada pelos sociólogos da estratificação social). E mesmo os gestos mais íntimos são filtrados por padróes sociais. Um modo "muito especial" de beijar é conforme e equivalente ao modo "muito especial" como outros o fazem. A diferença poderá residir numa mera questão de hálito, se acaso quem beija acabou de mascar uma chiclete com sabor a morango - coisa trivialíssima, pois todos os beijoqueiros costumam mascar pastilhas, provavelmente com o mesmo sabor a morango.

Não quero com isso dizer que o "projecto reflexivo do eu" (Giddens, Beck \& Lash, op. cit., p. 93) esteja alheado de uma boa dose de autonomia emocional. Mas quando os indivíduos se tornam reflexivos, o que se passa com essa autonomia emocional? Ela torna-se num tema e problema de permanentes preocupações e anseios. À medida que a tradição perde o seu império, a vida cotidiana abre-se a uma diversidade de opçôes que deixam os indivíduos pendurados em dilemas. Vejamos o que se passa no campo dos afectos e da sexualidade. Libertos de tradições e de constrangimentos morais, os indivíduos passam a construir-se a si mesmos, ao construírem as suas relações com os demais. Reflexividade que leva Giddens a falar de "relaçōes puras" (1995, p. 15) fundadas na "recompensa" que por si proporcionariam - recompensa que pressupõe, desde logo, o "compromisso", forma particular de confiança. Esta pureza imaculada talvez apenas exista na cabeça de Giddens. É mais prudente admitir que ao lado da recompensa e do compromisso haja também lugar para a desconfiança, o descrédito, o temor e o cepticismo 
- com relação ao(à) outro(a) e a si mesmo. A coabitação das "relações puras" com as "traições afectivas" é difícil de sustentar. Não por acaso Bauman (2003) advoga que é evitando compromissos, em particular os compromissos de longo prazo, que mais facilmente se evitam as armadilhas que impedem ou dificultam novos relacionamentos ou experiências amorosas. Outra alternativa é camuflar a traição por meio do fingimento - procedimento que pode viabilizar a durabilidade de muitos relacionamentos. Quando o fingimento é desmascarado surgem as desgastadas alegaçōes atenuantes do tipo "não resisti", "perdi a cabeça", enfim, desculpas que em nada abonam em favor das relações "puras" ou "simétricas", excepto quando o amante traído recompensa devidamente o traidor, pagando-lhe na mesma moeda.

Em contrapartida - e continuando a discorrer sobre a autonomia emocional que aparece associada ao "projecto reflexivo do eu" -, a experimentação que caracteriza muitos dos actuais encontros (e desencontros) amorosos revela claramente uma capacidade de autonomia mas, paralelamente, arrasta temores sobre os desempenhos que decorrem dessa autonomia. Desse modo se justifica o desenvolvimento de uma rentável indústria de excitantes sexuais cujo marketing nos inunda as caixas de correio electrónico. Podem aplicar, se quiserem, o conceito de empowerment que agora está tão de moda já que é de (im)potência social que estamos falando. É muito fácil teorizar sobre os mil e um posicionamentos de um acto sexual, incluindo as relações de simetricidade emocional ou erótica. Os manuais de sexologia propagandeiam reflexividades inimagináveis entre os parceiros, sendo clássica a que se baseia numa metaforização dos amantes em forma de números simétricos. Mas nem todas as dicas de retardamento orgiástico asseguram que a meta possa ser cortada ao mesmo tempo por ambos os parceiros.

Como quer que seja, em face dos dilemas radicais com relação aos quais a identidade é submetida na modernidade, os indivíduos esforçam-se por conseguir um domínio de si, por meio de uma profusão de instrumentos de reflexividade - terapias, manuais de auto-ajuda, consultórios de aconselhamento etc. - que integram sistemas de conhecimento "pericial" que, supostamente, nos deveriam merecer "confiança". Consultei o "correio sentimental" de algumas revistas "cor-derosa" - revistas que algumas mulheres compram e muitos homens fingem não $\operatorname{ler}^{10}$ - e do que me apercebi foi de uma flagrante tensão entre o desejo de experimentação e as ameaças de rejeição. Uma senhora da ci- 
dade do Porto queixou-se na revista Maria: "Tenho 38 anos e uma fantasia secreta: ser possuída em cima do lavatório da casa de banho. Já insinuei ao meu marido que gostaria de fazê-lo, mas ele disse-me que tal era impossível, porque sou demasiado gorda e o móvel era novo". ${ }^{11}$

O exemplo mostra como a "cultura do risco" até num recôndito banheiro se pode manifestar e como a "consciência do risco" se transforma num meio de "colonização do futuro". ${ }^{12}$ Com os teóricos da modernização reflexiva aprendemos que viver numa "sociedade de risco" significa viver em permanente atitude de cálculo com relação às nossas possibilidades de acção. Vale mais um móvel novo ou um prazer fugaz?

Também encontrei confissões enquadráveis no modelo de "modernização reflexiva” que joga com a experimentação bem-sucedida, mas normalmente vivida a sós, e não isenta de temores. Aliás, uma das razões pela qual a "reflexividade do eu" produz um conhecimento mais exacto e penetrante do "eu mesmo" é porque ajuda a diminuir a dependência com relação aos demais, no domínio do erotismo. Na revista Mulher Moderna, uma senhora questionava-se, apreensiva:

Vi um anúncio a um telemóvel [nome que em Portugal se dá ao "celular"] numa cadeia de televisão estrangeira que me fez despertar para um facto curioso. É que embora tenha uma vida sexual satisfatória, sempre me masturbei recorrendo ao uso de vibradores. Acontece que esse spot publicitário era sobre um telemóvel que vibra. Poderei usar o meu para esses fins, sem prejudicar a saúde? ${ }^{13}$

Já sabíamos que os celulares são multifuncionais. Dão para falar, enviar mensagens, jogar, fotografar, filmar, servem de agenda, de despertador etc. Mas a capacidade de os reconverter para funçôes sexuais mostra bem até onde pode chegar a modernidade reflexiva quando apoiada em "experiências mediadas" 14 - por novas (e móveis) tecnologias. A esta justaposição de componentes heterogéneos do conhecimento ou de informação Giddens (1995) dá o nome de "efeito colagem". A experiência global da modernidade faz com que as características íntimas da vida pessoal se abram às "experiências do cotidiano" (Giddens, Beck \& Lash, op. cit., p. 77) - experiências que já não se encontram apenas dependentes da tradição ou da vontade individual, mas de interferências tecnológicas várias.

Também encontrei confissões que tipificam o que Giddens designa de "sequestro da experiência" ou "privatização da paixão" (1995, p. 
199-215). É o caso do queixume de uma leitora da revista Maria: "Acho o comportamento de meu marido estranho. Durante o sexo, ele quer que eu grite. (...) Sinto vergonha dos vizinhos". ${ }^{15}$

A vergonha da leitora denota uma "privatização da sexualidade", subjugada ao poder do silêncio. É neste sentido que Giddens admite que a privatização da sexualidade corresponde a uma ocultação mórbida da vista (ou do ouvido, acrescento), ao dar-se uma reconstituição da sexualidade por meio da sua ancoragem a uma nova esfera de intimidade (Giddens, 1995). No entanto, o exemplo da Maria mostra que, neste caso, a privatização da sexualidade aparece também ligada a uma consciência moral, vulgarmente apontada como típica de sociedades tradicionais. Não há sentimento de vergonha sem essa consciência moral. Nos seus Três ensaios sobre a teoria da sexualidade, Freud utiliza a metáfora da "nudez da vergonha" para nos mostrar que o sentimento subjectivo da vergonha tem determinantes sociais. Para o efeito, Freud relaciona a vergonha com a nudez do corpo. Curiosamente, a palavra em alemão para vergonha (scham) tem uma raiz etimológica que também a remete para a área genital (die Scham); o monte pubiano, por exemplo, é schamberg. De que trata a vergonha, nesta acepção? Da exposição pública de uma região púbica - o que origina um sentimento correlativo que é o pudor. Estamos perante o embaraço de dar visibilidade a algo que é do foro do privado. $\mathrm{O}$ mesmo acontece quando, por vergonha, alguém tapa a cara com as mãos para não a expor a público. Ou quando a leitora da revista Maria se recusa a gritar durante o acto sexual, com receio dos vizinhos.

Desse modo, se é certo que com a modernidade reflexiva a sexualidade passou a ser "propriedade do indivíduo", a "identidade do eu" passou, por sua vez, a estar submetida a sentimentos de vergonha que convocam, em novos moldes, a questão do controle social. Assim sendo, há que destacar a tensão, despercebida a Giddens, entre o referido "sequestro da experiência" e o que doravante passaria a designar por tradicionalização reflexiva. Uso este conceito para acentuar a sobrevivência de uma ética de compromisso que não se estabelece necessariamente com o parceiro, mas, imaginariamente, com uma comunidade que, no caso do exemplo da Maria, é formada por ouvidos de vizinhos supostamente inquisitórios e censórios. A vizinhança e o temor (tradicional) que dela se tem sugerem uma reflexividade que medeia relações reguladas por uma moral - por natureza controladora. 
Ao contrário de Giddens, não creio que o "sequestro da experiência” (Giddens, 1995) ${ }^{16}$ arraste, inevitavelmente, um cabal sequestro da moral, ou um despojamento do social, fazendo com que a vergonha deixe de ser um fenómeno social para se situar no nível do mero terreno psicológico do "eu". Em contrapartida, a exposição pública de sentimentos privados, como acontece nas revistas cor-de-rosa, também relativiza, de certo modo, a ideia que Giddens rotula de "sequestro da experiência". Quando a leitora da Maria teme que as sonoridades da sexualidade cheguem aos ouvidos dos vizinhos podemos dizer que esse temor sugere uma privatização da sexualidade. Mas quando a mesma leitora escarrapacha os seus temores numa revista de grande circulação, nesse caso se dá a publicização (ainda que sob anonimato) do que se pretendia sequestrado.

Os temores associados aos desafios da experimentação são recorrentes nas confissões e dúvidas que recheiam as revistas cor-de-rosa. Dúvidas de quem vive dilemas da modernidade. Por aqui vemos que a reflexividade que interessa aos etnometodólogos difere significativamente daquela que preocupa os teóricos da modernização reflexiva. Ao passo que os primeiros se questionam sobre como rotineiramente se chega ao significado, Giddens, por exemplo, interroga-se sobre como conscientemente se chega à segurança ontológica. ${ }^{17}$ Mas o interessante é constatar que, por caminhos da rotina, a insegurança ontológica também se acalma quando se ganha consciência de que, afinal, ela é um problema compartilhado como acontece com os dilemas que inundam os "correios sentimentais" das revistas de especialidade. As respostas a esses dilemas (por mais fictícios que o sejam) instauram um sistema pericial de aconselhamento por intermédio do qual se promove a auto-reflexividade. Desse modo, os "conselhos avulsos" são manifestações de uma modernidade reflexiva, ao ajudarem quem os lê a organizar e a modificar os aspectos mais íntimos da sua vida privada. O que hoje em dia chamamos de intimidade é também reflexo de modernas influências globalizadoras, e esta é uma das faces da modernidade reflexiva. Os leitores das revistas cor-de-rosa (dirigidas a mulheres, mas também lidas por homens) vêem as suas relações amorosas reflexivamente organizadas em função dos fluxos de informação a que acedem. As subjectividades, aqui, voltam a ganhar uma dimensão social. Muitos hábitos pessoais tornam-se efectivamente colectivos uma vez que sejam conformados pela difusão, ou pelo resultado de influências 
globalizantes, categorizáveis sob a designação de reflexividade comunicacional. Esta, contudo, também assegura um maior protagonismo individual. Se a modernização reflexiva aparece como uma teoria dos poderes crescentes dos actores sociais com relação às estruturas sociais, é porque o tecido social se revigorou criando oportunidades que permitem esse maior protagonismo individual. Essas oportunidades são geradas por novas "estruturas de informação e comunicação" (Giddens, Beck \& Lash, op. cit., p. 137), as quais contribuem para uma espécie de "acumulação reflexiva" de capital de informação (idem, ibid., p. 145).

Esta "febre informativa" tem "efeitos colaterais". ${ }^{18}$ A busca por informação é frequentemente ultrapassada pelo desejo de se ser fonte de informação. A este protagonismo individual dou o nome de emplastramento reflexivo. No caso da televisão portuguesa, por exemplo, o conceito pode ser caricaturalmente simbolizado por um famoso deficiente mental, a que dão o nome de "emplastra" por se colar às câmaras de televisão. Pagam-lhe jantares e hotéis porque simplesmente é um "homem público", em virtude da fama da televisão - reflexividade que garante notoriedade. ${ }^{19} \mathrm{O}$ que o emplastra faz é correr Portugal de ponta a ponta, na peugada das equipas de reportagem televisivas, colandose intrusivamente nos planos de filmagem de qualquer reportagem "ao vivo". Trata-se de um comportamento insólito, mas equivalente ao de alguns políticos e opinion makers, com idêntica paixão pelas câmeras, nomeadamente em horário nobre. Aqui, o meu alinhamento com Giddens (1995, p. 42), se bem o interpreto, não sofre vacilação: em condições de modernidade, os meios de comunicação não reflectem realidades, em certa medida apenas as configuram.

\section{Morais e identidades reflexivas}

A ética kantiana partia de um pressuposto fundamental: se as regras da moral são racionais, devem ser iguais para todos, todos iguais perante uma igual razão. A partir de uma justificação racional da moral, concebiase um guia de acção por intermédio de critérios impessoais que possibilitavam um marco ético compartilhado. Agora, ao que assistimos é a uma desordem da moral expressa na existência de múltiplas moralidades, frequentemente conflitantes entre si. Isso acontece porque o núcleo duro da acção moral se tem deslocado do societal para o individual. São as atitudes, os sentimentos e as preferências individuais que crescentemente se consti- 
tuem em eixos axiológicos da acção, segundo critérios pessoais que tendem a fazer da moral um juízo individual.

Estou numa fila de trânsito. A meu lado passa um carro que dá "pisca-pisca", solicitando-me prioridade de passagem para integrar a fila em que me desloco, na tentativa de me tomar a dianteira. Dou-lhe passagem? É um dilema que nos leva a pensar que as virtudes podem ser meras cortesias dependentes de moralidades ou éticas contextuais. O mais provável é que não lhe ceda passagem. Colo o meu carro ao da frente eliminando, pura e simplesmente, qualquer veleidade de intrusão. A buzinada que lhe dou é um sinal sonoro de repulsa perante "golpadas" que não respeitam a ordem da fila. Se a buzina do carro intruso responde à do meu, vacilo ante a tentação de lhe exibir malabarismos com os dedos da mão porque, apesar de tudo, ainda me norteio por princípios morais que resistem a derrocadas iminentes.

No entanto, as regras morais e éticas - neste caso, de obediência à ordem da fila de trânsito - mudam em virtude do comportamento do condutor que me pede passagem: se é uma moça que me esboça um sorriso simpático provavelmente lhe dou passagem; se o condutor em questão me faz um gesto de agradecimento antecipado, na expectativa de lhe poder vir a dar passagem, é provável que ceda à chantagem do "agradecimento antecipado". Ou seja, o que vemos é que os juízos morais ou éticos acabam por ser expressão de preferências pessoais, modeladas por coordenadas situacionais. $\mathrm{O}$ meu agir já não surge regulado por necessidades imperativas de obedecer a leis impessoais obediência que fundamentava uma moral pública abstracta -, mas é um agir contingencial. Uma vez que cada um de nós é juiz de suas próprias acções, as referências morais ou éticas tendem a diluir-se na medida em que a sua legitimidade é sempre de natureza contextual ou interaccional. As condutas cotidianas continuam a obedecer a regras tácitas, em que se espelham alguns consensos sociais, mas de nós depende também a capacidade de as manipular ou superar.

A modernidade arrasta uma tensão entre a consciência que os indivíduos têm de suas próprias contingências e a necessidade de responderem a seus próprios destinos. Nessa medida, a modernidade remete para um mundo que é produção de sujeitos ao mesmo tempo que estes se vão construindo a si mesmos como autores, num jogo de espelhos. A própria natureza - seja ela determinada pelo "ambiente" ou pela "tradição" - torna-se cada vez mais uma tomada de decisão. Os efeitos da 
"destradicionalização" fazem-se sentir, sobremaneira, na vida íntima e sexual das pessoas: "a gravidez de uma virgem é agora possível; indivíduos sozinhos e casais do mesmo sexo podem ter filhos próprios. Os pais podem escolher o sexo dos filhos" (Giddens, Beck \& Lash, op. cit., p. 225). No limite, os indivíduos são livres para escolher o seu próprio sexo. E, para nos embaralharem, podem até esconder, por opção própria, as suas preferências sexuais.

Contaram-me há dias uma situação caricatural que, apesar de anedótica, pode na realidade deixar muitos amantes num dilema angustiante com relação à identidade do outro. Num quarto de hotel, dois amantes, ultrapassados os momentos de euforia, entram na fase do "depois", aquela em que relaxadamente se fuma um cigarro ou se bebe um copo de whisky:

Ele: Esses seus peitos... Incrível como podem estar tão firmes, estando você já à beira dos quarenta.

Ela: Cinquenta! $200 \mathrm{ml}$ de silicone de cada lado.

Ele: Viva a medicina!

Ela: Mas esse teu sorriso é demais! Pôe-me louca!

Ele: 32 dentes implantados. Mais de 16 horas na cadeira do dentista.

Ela: Viva a odontologia!

Ele: Gostei dos teus cabelos. São naturais?

Ela: Aplique. Estavam curtinhos. Não quis esperar que crescessem. Mas os seus são...

Ele: Entrelaçados. Não dá para reconhecer. Posso até nadar com eles.

Ela: Há mais de duas horas que estamos na cama e você ainda não baixou o mastro. Como consegue? Viagra?

Ele: Prótese. Depois do acto é só dobrar.

Ela (perturbada): Pensei que fosse pura excitação.... O seu arfar... o seu calor... Ele: Mas fiquei excitado, juro... Também, com esse seu bumbum...

Ela: Silicone. Nas barrigas das pernas também tem um pouco.

Ele: Onde mais você mexeu?

Ela: Pálpebras, maçãs do rosto, queixo, pescoço, lipo na barriga, cintura... e também fiz a "preciosa"...

Ele: Você quer dizer...

Ela: Exactamente! 


\section{Ele: $\mathrm{O}$ que você fez?}

Ela: Mudança de sexo. O meu nome é Valdemar.

Como vemos, as ameaças e situações de risco que caracterizam a modernidade reflexiva podem ocorrer nos mais impensáveis contextos. Num mundo social em que a reflexividade se tornou elemento constituinte central, a complexidade dos cenários em que ela ocorre é embaraçante, deixando-nos por vezes desarmados. Tem razão Giddens quando afirma que a modernidade se tornou experimental:

Queiramos ou não, estamos todos presos em uma grande experiência, que está ocorrendo no momento da nossa acção (...), mas fora do nosso controle, em um grau imponderável. Não é uma experiência laboratorial, porque não controlamos os resultados dentro de parâmetros fixados - é mais parecida com uma aventura perigosa, em que cada um de nós, querendo ou não, tem de participar. (Giddens, Beck \& Lash, op. cit., p. 76)

Nos cenários mais banais da vida cotidiana experimentam-se novas identidades, joga-se com a ambiguidade, alimentam-se dúvidas e cepticismos que nos deixam baralhados. O dilema básico da interacção é o de nos mostrar que os mesmos comportamentos que podem ser tomados como sinceros e honestos podem também ser usados para simular essa sinceridade e honestidade. As identidades perderam a estabilidade de outrora, tornaram-se crescentemente difusas e artificiosas, são trabalhadas em contextos de maiores (e mais livres) possibilidades de escolha (Wagner, 1994). No entanto, a reflexividade não se justapõe ao "ser reflexivo", como se os nossos contemporâneos fossem mais sabedores ou conscientes que os seus antepassados. ${ }^{20}$ A propriedade de "reflexivo" sugere apenas que efeitos não previstos das acçôes se repercutem por todo lado de forma insubmissa e rebelde, ou, como sugere Latour: ganhamos consciência de que a consciência não significa controle completo (2003, p. 36).

\section{Conclusão}

Para Ulrich Beck (1993), os efeitos perversos da modernidade reflexiva podem gerar um cotidiano "culturalmente cego", sempre e quando os nossos sentidos anunciem uma normalidade que, sem se saber, dá guarida 
ao perigo. Neste caso, o cotidiano, ele próprio, corre risco de se enredar nas teias da alienação, fonte de cegueira dessa normalização do cotidiano, traduzida numa compulsão à repetição. A compulsividade - afirma Giddens - é uma incapacidade de escapar ao passado (Giddens, Beck \& Lash, op. cit., p. 85). Quando as tradições da vida cotidiana começam a ranger e a ceder sob o impacto da modernidade, cedem também as estruturas estabilizadoras de uma "memória coerente" (Giddens, 1995, p. 86). É aqui que a auto-identidade começa a ser afectada, é neste ponto que a tradição começa a ser transformada em compulsão. É esta compulsividade que - segundo Giddens - traduz-se numa inclinação emocional para a repetição:

O passado continua vivo, mas, em vez de ser construído de modo activo de acordo com a tradição, tende a dominar a acção quase de um modo causal. A compulsividade, quando socialmente generalizada, é, na verdade, tradição sem tradicionalismo: repetição que se põe no caminho da autonomia, em vez de estimulá-la. (Idem, ibid., p. 89)

O ritual é um meio prático de garantir a preservação da tradição. Não creio, todavia, na inevitabilidade da "cegueira cultural" do cotidiano. Embora adormecidos, os poderes fascinantes da reflexividade transformadora encontram-se enraizados no cotidiano. A estrutura dilemática da sociedade não significa - pelo contrário - que o futuro seja mero eco reflexivo de um jogo cujas regras são inalteráveis, nem que esteja dependente de puros efeitos de contingência. $O$ futuro constróise num dia-a-dia que embrulha o passado no presente. De acordo com as teorias da modernização reflexiva, quanto mais as sociedades são modernizadas mais os indivíduos adquirem a capacidade de reflectir sobre as condições da sua existência e, desse modo, mais possibilidades têm de as modificar (Giddens, Beck e Lash, op. cit., p. 207).

Se não quisermos ver o cotidiano como efeito de reflexividades impositivas (vindas de cima), há que o olhar de "pernas para o ar", como acontece com os sistemas emergentes, de tipo bottom up (Johnson, 2003). Tais sistemas criam conhecimento a partir de baixo. Os sistemas bottom up contrapõem-se aos modelos deterministas top down que são característicos de reflexividades impositivas. Para que sejam verdadeiramente emergentes, os sistemas bottom up devem inscrever-se numa lógica de reflexividade transformadora - o que somente é possível quando as interacçóes locais resultem em algum tipo de macrocomportamento 
observável. ${ }^{21}$ Tanto a aprendizagem quanto o actuar bottom up dão-se no mundo da vida cotidiana - usando "informação local" que pode levar a um "saber global". O SimCity ${ }^{22}$ foi um dos primeiros jogos a explorar os fascinantes poderes da emergência bottom up. Nesse jogo, o mundo bottom up está presente pelas possibilidades de auto-organização de comportamento emergente. Ao contrário das cidades planeadas de modo top down, a vitalidade das cidades vem dos que informalmente circulam no espaço público da cidade: a rua. A verdadeira magia da cidade vem de baixo e não dos arranha-céus onde a vida social parece estar enjaulada.

Vimos que a modernidade impositiva é corolário do reflexo das estruturas nas acções. Em contrapartida, a reflexividade transformadora é, sobretudo, reflexo do desfalecimento da clássica distinção entre estruturas e acçōes, é a anunciação do fim desse dualismo. É neste sentido que entendo a reflexividade transformadora como âmago da modernidade reflexiva. A possibilidade de o cotidiano aparecer como um cenário bottom up deriva do facto de, em contextos pós-tradicionais, muitas das actividades cotidianas encontrarem-se abertas à escolha, a uma multiplicidade de possibilidades e de opções, sendo a sua concretização uma manifestação de poder. No entanto, reflexividade transformadora tanto pode significar protagonismo quanto falsa consciência de libertação do eu.

O protagonismo transformador é mais provável em situações de reflexividade cognitiva. Foi o que aconteceu quando, nas manifestaçóes em favor da despenalização da interrupção voluntária da gravidez, algumas mulheres portuguesas, conscientemente, inscreveram nas suas barrigas a palavra de ordem "aqui mando eu". Todavia, embora se possa falar de uma reflexividade ubíqua no mundo contemporâneo, ela é mais reflexiva para uns que para outros (Erickson, 1996). De novo somos compelidos a considerar as condiçôes estruturais da reflexividade. É legítimo ler num registo de modernidade reflexiva a situação de uma mãe solteira que optou por não interromper a sua gravidez e se vê a braços com um filho não desejado? Como vemos, não estão apenas em causa estruturas sociais tradicionais, mas estruturas de informação. No exemplo dado, informação (e o acesso a ela) no que respeita aos métodos contraceptivos. No capitalismo industrial, as oportunidades de vida e as desigualdades de classe dependiam dos lugares ocupados nos sistemas de produção; em contrapartida, na modernidade reflexiva é, sobretudo, relevante o lugar ocupado nos sistemas de informação, uma vez que esta é usada como recurso notável para a realização de projectos identitários. 
A informação pode ainda estar associada, por meio da publicidade, a formas de reflexividade de natureza mimética. Com efeito, no cotidiano não há apenas lugar à reflexividade cognitiva. Há também lugar a uma reflexividade estética. Esta dimensão estética da reflexividade é o princípio básico do "individualismo expressivo" que caracteriza a vida cotidiana do capitalismo de consumo contemporâneo. Tal reflexividade ocorre por intermédio de um modo de mediação não conceptual, mas mimético. O "dilema da gravata" mostra bem que a reflexividade estética é reflexiva na medida em que opera mimeticamente na experiência do cotidiano. Os portadores de gravata adoptam o tipo de porte proposto pelas pautas dominantes da moda ou da cultura. Convertem-se, por isso, numa réplica do que os outros são e do que esses outros esperam que cada um seja.

É nas teias desta reflexividade estética que ritualizamos identidades, as modificamos e as representamos. A ideia de self (si próprio) envolve um processo reflexivo em que o indivíduo se toma a si mesmo como objecto. Quem sou eu? O que devo fazer? Vou para a mesa-redonda com ou sem gravata? Dúvidas que levam ao questionamento do me (mim), a forma como me olho por intermédio do olhar dos outros. ${ }^{23}$ Somos sempre um outro de alguém, o outro de um outro (Augé, 1994). O que pensamos de nós próprios é o reflexo de olhares cruzados que vemos projectados sobre nós mesmos. Por isso, a minha decisão de ir com ou sem gravata para a mesa-redonda foi reveladora de uma capacidade de decisão, revestida de reflexividade. Mas a minha decisão levou em conta o que os outros meus colegas poderiam pensar de mim. Dois espelhos, ao reflectirem-se um no outro, acabam por se reflectir cada um em si mesmo. Por esta razão não penso que a individualização apague os reflexos da socialização.

Queria, finalmente, encaminhar minhas deambulações para três conclusões finais. Primeira, a modernidade não deve apenas ser entendida como um empolamento de opções. Ela está também na origem de crescentes diferenciações - entre quem pode ou não aceder à realização de identidades projectadas. A possibilidade de reflexividade transformadora será tanto mais socialmente emancipatória quanto mais protagonizada por grupos sociais sujeitos a algum tipo de dominação ou exploração: por exemplo, jovens que procuram afirmar a sua identidade por meio de culturas performativas e estéticas; ou, ainda, mulheres que, no campo profissional, manifestam a sua vontade de ser reconhecidas pelo que fazem - e 
não apenas pelo que, por natureza, são (Lipovetsky, 1999). Segunda, o processo de personalização que vivemos vai em paralelo com um processo de reciclamento do social. O "dilema da gravata" mostra que a liberdade subjectiva não deve apenas conceber-se em termos de insubmissão às convençôes. A subjectivação não se opõe à socialização. Terceira, a individualização pode gerar uma falsa consciência de libertação. A crença de que somos detentores de um poder (que nada tem de contrapoder) pode significar uma reflexividade alienante, que projecta a "cegueira cultural" do cotidiano num futuro cujo presente o contém. Como modificar o presente para evitar esse futuro? Eis como esta simples pergunta traduz uma reflexividade do presente sobre si mesmo, no espelho do futuro - prova evidente de que a reflexividade transformadora se inscreve numa temporalidade social.

\section{Recebido em outubro de 2006 e aprovado em março de 2007.}

\section{Notas}

1. Sobre a "contextualização sociológica", ver Pais (2003).

2. Tenhamos em conta, por exemplo, a proposição de Ulrich Beck: "Quanto mais as sociedades são modernizadas, mais os agentes (sujeitos) adquirem capacidade de refletir sobre as condiçôes sociais da sua existência e, assim, modificá-las" (p. 210).

3. A modernidade reflexiva pode significar um retorno da tradição. Por exemplo, o tráfego de uma cidade pode tornar-se tão caótico que faz com que seja mais rápida a deslocação a pé. $\mathrm{O}$ atendimento nas urgências de um hospital pode ser tão demorado (nomeadamente em hospitais portugueses) que pode ser mais confortável ficar em casa à espera de que a maleita passe.

4. A este propósito, diz Giddens (Giddens, Beck \& Lash, 1995, p. 219-220): “Actualmente, a característica de nossas vidas é o que se poderia chamar de 'incerteza fabricada'. De repente, muitos aspectos de nossas vidas tornaram-se abertamente organizados apenas em termos de 'suposiçôes de cenários"'.

5. Pensa-se na "Eurocopa" como promoção do espírito desportivo e logo surge a ameaça dos hooligans. Criam-se instituições de acolhimento a crianças desprotegidas e, por efeito perverso, logo emergem condições de possibilidade para as violar. Na "sociedade de risco", os conflitos de distribuição dos "bens" (rendimentos, empregos, segurança social) dão lugar aos conflitos de distribuição dos "malefícios" (quem paga a crise? Onde instalar a central de tratamentos de lixos tóxicos?). Ver Beck, "A reinvenção da política: rumo a uma teoria da modernização reflexiva" (in: Giddens, Beck \& Lash, op. cit., p. 16-17).

6. A "pega de caras" é uma lide (performance) tauromáquica, tipicamente portuguesa, em que forcados (homens que pegam o touro), posicionados em fila, incitando o touro, tentam imobilizá-lo logo que este investe para os chifrar. O forcado da dianteira tenta encaixar a barriga no focinho do touro, segurando-se pelos cornos, enquanto os companheiros o ajudam no desafio de o imobilizarem. 
7. Por sorte, a minha mesa-redonda foi a última do Congresso, acantonada à sessão de encerramento.

8. O conceito é desenvolvido por Giddens (1995, p. 85).

9. Contei duas excepções: um colega da Universidade do Minho que - hipótese plausível -, por ser da casa que acolhia o Congresso, terá feito questão de nos receber informalmente, manifestando desse modo a sua hospitalidade; e um colega da Universidade de Coimbra que chegou à sua mesa-redonda com mais de 30 minutos de atraso, sendo possível admitir que, por efeito dos "eventos sociais" da noite anterior, terá adormecido, não tendo tido tempo de se confrontar com o dilema da gravata, ou, então, terá chegado atrasado por ter andado à procura da gravata que, eventualmente, esqueceu em Coimbra.

10. Para o período de 2000 a 2004 consultei as revistas Maria, Ana e Mulher Moderna. Informaram-me que, no Brasil, existem revistas semelhantes: Contigo, Carinho etc.

11. Maria, de 25 de abril a 1 de maio de 2001 .

12. Segundo Giddens, a "cultura do risco" é um aspecto fundamental da modernidade sendo que a consciência desse risco constitui um meio de colonização do futuro. Cf. Giddens (1995).

13. Mulher Moderna, 12 a 18 de julho de 2001.

14. O conceito é desenvolvido por Giddens para ilustrar a intervenção de influências várias na experiência sensorial humana. Cf. Giddens (1995).

15. Maria, 21 a 27 de novembro de 2003.

16. "Sequestro da experiência" porque, segundo Giddens (1995), é fugaz e escasso o contacto directo com acontecimentos e situaçóes que vinculam a vida individual a questôes mais amplas da moral.

17. Este confronto é estabelecido por Scott Lash, "A reflexividade e seus duplos: estrutura, estética e comunidade” (Giddens, Beck \& Lash, op. cit., p. 143).

18. A expressão é de Ulrich Beck (Giddens, Beck \& Lash, op. cit., p. 208).

19. A tal ponto que já lhe criaram uma página na net: <http://emplastro.no.sapo.pt>

20. Idéia que tomo de Bruno Latour (2003, p. 35-48).

21. Ideia que alguns sociólogos desenvolvem no âmbito da Actor Network Theory (ANT). Ver Law e Hassard (1999). Curiosamente, os sistemas bottom up têm sido ilustrados a partir da "lógica de enxame" que governa a interacção das formigas. O principal mecanismo da lógica de enxame é a interacção entre formigas vizinhas: tropeçando umas nas outras, ou nas trilhas de feromônio de outras, no reconhecimento das tarefas ("a minha tarefa é a colheita"), na atracção da trilha ("há comida ali”), no comportamento de alarme ("fujam!"), nas condutas necrofóricas ("vamos enterrar estas colegas mortas"). Ver também Johnson (2003, p. 55). É claro que, na esteira de Johnson, os padrôes de relacionamento que criamos são substancialmente mais complexos que os das formigas. Conscientemente tomamos decisōes sobre onde morar, comer ou passear; não somos simplesmente levados por trilhas de feromônio, como acontece com as formigas. Os poderes de emergência bottom up são de natureza auto-reflexiva.

22. Jogo informático lançado em 1990 por Will Wright, dos mais famosos jogos de computador que até hoje apareceram.

23. A forma como me olho por intermédio do olhar dos outros ("me") pressupõe uma consciência do eu ("I" abstracto) e é por essa consciência que passa o self. 
Referências bibliográficas

AUGÉ, M. Le sens des autres: actualité de l'anthropologie. Paris: Fayard, 1994.

BAUMAN, Z. Liquid love: on the frailty of human bonds. Oxford: Polity, 2003.

BECK, U. Ecological enlightenment. New York: Humanity, 1993.

BRUCKNER, P. La tentación de la inocencia. Barcelona: Anagrama, 1999.

CALVO, G. Nacidos para cambiar. Madrid: Taurus, 2001.

COULTER, J. (Comp.). Ethnomethodological sociology. Aldershot: Edward Elgar, 1990.

ERICKSON, B. Culture, class and connections. American Journal of Sociology, Chicago, v. 102, n. 1, p. 217-251, 1996.

FEATHERSTONE, M. Consumer culture and postmodernism. London: Sage, 1991.

FINK, T.; MAO, Y. As 85 maneiras de dar um nó de gravata: a ciência e a estética dos nós de gravata. Lisboa: Dom Quixote, 2002.

GIDDENS, A. Modernidad $i$ identidad del yo: el yo y la sociedad en la época contemporánea. Barcelona: Península, 1995.

GIDDENS, A.; BECK, U.; LASH, S. Modernização reflexiva. São Paulo: UNESP, 1995.

GOFFMAN, E. A apresentação do eu na vida de todos os dias. Lisboa: Relógio d’Água, 1993 (1. ed. em inglês 1959).

JAVEAU, C. Variations sur la cravate. Revue de l'Institut de Sociologie, Bruxelas, n. 2, p. 289-291, 1971.

JOHNSON, S. Emergence: the connected lives of ants, brains, cities and software. New York: Scribner, 2001. (JoHNSON, S. Emergência: a vida integrada de formigas, cérebros, cidades e softwares. Rio de Janeiro: Jorge Zahar, 2003). 
LASH, S.; FRIEDMAN, J. (Ed.). Modernity \& identity. Oxford: Blackwell, 1992.

LASH, S. Reflexivity as non-linearity. Theory, Culture \& Society, Nottingham, v. 20, n. 2, p. 49-57, 2003.

LATOUR, B. Is re-modernization occurring: and if so, how to prove it. Theory, Culture \& Society, Nottingham, v. 20, n. 2, p. 35-48, 2003. LAW, J.; HASSARD, J (Ed.). Actor network and after. Oxford: Blackwell, 1999.

LIPOVETSKY, G. La tercera mujer. Barcelona: Anagrama, 1999. (1. ed. em francês 1997).

PAIS, J.M. Vida cotidiana: enigmas e revelações. São Paulo: Cortez, 2003.

SWEETMAN, P. Twenty-first century disease?: habitual reflexivity or the reflexive habitus. The Sociological Review, Keele, v. 51, n. 4, p. 528-549, 2003.

WAGNER, P. A sociology of modernity: liberty and discipline. London: Routledge, 1994.

REVISTAS: Maria, Ana e Mulher Moderna (para o período de 2000 a 2004). 